\title{
The Consumer Market in the New Economy
}

\author{
Kheda Murtazova ${ }^{1, *}$, and Madina Abdulkadirova ${ }^{2}$ \\ ${ }^{1}$ Chechen State University, 364024 Grozny, Russia \\ ${ }^{2}$ Grozny State Oil Technical University named after academician M.D. Millionshchikov, 364061 \\ Grozny, Russia
}

\begin{abstract}
The active globalization of the modern world is causing ever more severe challenges to national economies. Economies that adequately and timely respond to these challenges form the core of the world economic system. The only real opportunity to overcome the prevailing negative trend is the creation of an innovative economy with powerful internal sources of development that allow maintaining (at least) and strengthening (as a norm) the competitiveness of the Russian economy in the context of the rapid development of the rest of the world. The key manifestation of the formation of a new type of economy was the acceleration of the rate of investment in intangible assets and the creation of conditions for the constant reproduction of knowledge and its implementation in new high-tech products and services.
\end{abstract}

\section{Introduction}

Economy is a system with two positive connections: as social needs grow, it transforms and develops its basis [3]:

1. The material basis for meeting these needs, the complication of which, in turn, generates new needs. The quantitative growth of needs is possible with an extensive growth of the basis within the framework of natural constraints (resource, territorial);

2. Qualitative - with an appropriate qualitative transformation of the technological basis. The severity of natural limitations sets a powerful incentive for a qualitative transformation of the existing system of technologies, which, in turn, creates an objective opportunity for the emergence of new needs.

A clear distinction between economic growth and economic development was introduced by J. Schumpeter [10]: "Put as many post carriages in a row as you like - you will not succeed in the railroad". Economic growth, therefore, is an increase in production and consumption of the same goods and services (in particular, postal carriages) over time. Economic development is, first of all, the emergence of something new, previously unknown (for example, railways) or innovation.

Schumpeter defined innovation by the following criteria [10]:

- creation of a new product, with which consumers are not yet familiar, or a new quality of the product;

\footnotetext{
*Corresponding author: fu.ggni@mail.ru
} 
- the creation of a new method of production that has not yet been tested in a given branch of industry, which is not at all necessarily based on a new scientific discovery and may consist in a new form of commercial circulation of goods;

- opening a new market, i.e. a market in which a given branch of industry in a given country has not yet traded, regardless of whether this market previously existed; - the discovery of a new source of factors of production, regardless of whether this source existed earlier or had to be created anew;

- the creation of a new organization of the industry, for example, the achievement of a monopoly or the elimination of a monopoly position.

\section{Definition of "New Economy"}

In recent years, the term "new economy" has been gradually transformed into the concept of "innovative economy". An innovative economy [2] is a type of economy based on the flow of innovations, on constant technological improvement, on the production and export of hightech products with high added value and the technologies themselves. The presence of an innovation flow and its strength is determined by the nature of the synergistic relationship of national advantages in the existing system of technologies, the ability of workers to effectively use the existing technological system (the quality of human capital) and the system of institutions that sets the stability and quality of development of technological and social systems.

The innovation stream, in turn, consists of product and process innovations. Product innovation includes the development and implementation of technologically new and significantly technologically advanced products. Process innovation includes the development and implementation of technologically new or technologically significantly improved production methods, including methods of transferring products (production methods of logistics, supply of goods and services, and in ancillary activities).

The innovation economy is based on achievements in technological innovation, changes in business organization and state economic policy [4].

Technological innovation is primarily understood as information technology. Major breakthroughs in the information era have resulted from the convergence of technologies for fast information processing, cheap data storage and fast communication [6]. It was here that the first successes were achieved in noticeably reducing the cost of production, storage and transmission of data. In the $1990 \mathrm{~s}$, these processes accelerated sharply: the productivity of computers grew rapidly, the bandwidth of communication networks increased, and the cost of traffic, on the contrary, increased. It should also be noted that the current state of industrial production in Russian regions objectively does not allow a quick transition to an innovative path of development in the real sector of the economy.

Each of these innovations taken separately, no matter how significant it may be in itself, would not lead to those large-scale transformations of companies and consumer behavior, which determined the emergence of the new economy. The new economy emerged as a result of the synergistic effect of convergence of these technologies, which took place in a fairly short period of time. Indeed, the economies of developed countries began to fully benefit from such innovations as a computer, cell phone, fiber optic, lasers, only from the second half of the 90 s of the last century, although they were invented much earlier [5]. It was by this time that these innovations were massively integrated into the business.

Fierce competition forces companies to bring new products to the market and master new technologies extremely quickly. At the same time, know-how is becoming more and more complex. Under these conditions, the complete control of an individual company over the entire innovation cycle becomes economically ineffective [7]. The innovation race with its uncertainty, high costs and, accordingly, the huge cost of making mistakes in determining 
the viability of an innovative solution is won by those companies that manage to work in new institutional formats. First of all, it is the ability and desire to work with such institutions as venture funds, consulting companies specializing in supporting the implementation of advanced technologies, private companies that are ready to take on the risks of mastering a certain part of an innovative technology. Opportunities opened by information technologies for processing huge amounts of information presuppose the availability of appropriate technical means and software. Advances in some technologies "inevitably" lead to advances in adjacent areas. Information technologies are becoming innovations that create a new market or fundamentally change an existing one [8]. So, for example, without information technologies and the corresponding hardware and software, modern advances in genetic engineering would not be possible, which, in turn, radically change the field that was initially far from information technology - agriculture.

A simplified understanding of the essence of the new economy is widespread today. It is believed that the acquisition and implementation of new technology automatically leads to increased productivity, guaranteed profits, and the creation of new jobs. Practice does not support this naive technological determinism. It is impossible to create a new economy without transforming the business environment [3]. Innovative companies are remarkable not because they tend to use new technologies, but because they completely restructure their entire business process (including production, supply, customer relations, corporate boundaries) within the framework of these technologies, making it more efficient. efficient and integrated.

\section{Features of the Organization of Innovative Activities in Russia}

In world statistics, there are four main types of innovation:

- research and development carried out in-house;

- research and development carried out by third parties;

- purchase of machinery, equipment, software;

- acquisition of new technologies.

Russian statistics rarely do without the article "other" (usually this is one of the most significant articles) [5]. The case under consideration is no exception. "Other costs for technological innovations" in the Russian Federation amount to almost 20\%, which greatly complicates the comparison of domestic results with foreign ones. the introduction of innovations, in the understanding of Russian business, is not so much the independent development of new products and technologies and not even ordering such work to thirdparty organizations and, moreover, not the acquisition of new technologies, but a simple purchase of machinery and equipment that allows to produce either new products or improve existing technological process. The point, of course, is not that process innovation is "better" than product innovation.

Process innovations are in a sense primary, and product innovations are secondary. Indeed, the new technology makes it possible to create not just new products, but products of new technological quality [7]. It is possible (and necessary) to create new products on the existing technological basis, but a qualitative breakthrough cannot be achieved without introducing process innovations along this path. The low activity of domestic business in the modernization of its technological base limits it in 121 opportunities for product innovation, reduces its competitiveness in relation to foreign manufacturers, which take a more active position in the technological progress itself. Thus, the Russian business adheres to a rational, but limited strategy focused on minimizing costs and risks in innovation (Table 1) [9]. The flip side of it is a course towards imitation, and not towards developing your own innovations. The strategy is admissible, but there is no need to talk about innovation leadership within its framework [6]. 
Table 1. Structure of expenditures on technological innovations by type of innovative activity in the Russian Federation in 2018-2020,\%

\begin{tabular}{|l|c|c|c|}
\hline \multirow{2}{*}{ Type of innovation } & \multicolumn{3}{|c|}{$\begin{array}{c}\text { Extractive, manufacturing, production and } \\
\text { distribution of electricity, gas and water }\end{array}$} \\
\cline { 2 - 4 } & $\mathbf{2 0 1 8}$ & $\mathbf{2 0 1 9}$ & $\mathbf{2 0 2 0}$ \\
\hline Research and development & 20,6 & 14,9 & 20,4 \\
\hline Manufacturing design & 7,4 & 5,5 & 5,4 \\
\hline $\begin{array}{l}\text { Purchase of machinery and } \\
\text { equipment }\end{array}$ & 54,5 & 60,9 & 55,2 \\
\hline $\begin{array}{l}\text { Acquisition of new } \\
\text { technologies }\end{array}$ & 1,3 & 0,9 & 1,9 \\
\hline Purchase of software & 1,2 & 0,9 & 1,3 \\
\hline $\begin{array}{l}\text { Other types of pre- } \\
\text { production }\end{array}$ & 7,3 & 8,5 & 7,8 \\
\hline $\begin{array}{l}\text { Personnel education and } \\
\text { training }\end{array}$ & 0,2 & 0,4 & 0,6 \\
\hline Marketing research & 0,6 & 0,3 & 0,2 \\
\hline Other costs & 7 & 8 & 7,2 \\
\hline
\end{tabular}

As a result of the implemented expenditures on technological innovation, a growing number of newly created technologies have become. New, however, the overwhelming majority can be called only with some stretch. These technologies are new for Russia, but fundamentally new, having no world analogues, are much less - about 10\% [11]. Almost half of the newly created technologies are concentrated in production, processing and assembly, somewhat less in design and engineering, a significant number in communications and control, as well as in automated surveillance equipment.

\section{Conclusions}

In recent years, a new property of the global economy has become increasingly apparent: it is becoming more and more regulated and manageable. The developed countries are increasingly forming the core of the new economy and its periphery and semi-periphery. The countries of the technological core determine the economic and, as a consequence, the political configuration of the modern world, and the rest are in their orbit, using (if they do not try to pursue too independent policies) the benefits of progress generated by the core.

The fundamental difference between the core and the periphery is that the countries of the core may or may not allow the countries of the semi-periphery, and especially the periphery, to join the global streams of value creation. The country's non-inclusion in the global economy leaves it outside the framework of globalization processes, which gradually leads to the marginalization of the economy of such a country.

\section{References}

1. A. Auzan, G. Satarov, Economic Issues, 6, 65 (2018)

2. S.Yu. Barsukova, A.V. Ledeneva, Economic Issues, 118 (2020)

3. S.V. Kazantsev, Region: economics and sociology, 111 (2018)

4. V.V. Kuleshov, G.A. Untura, A.V. Evseenko, Science, education, innovation centers: regional aspects of integration, 95 (2020)

5. The main parameters of the forecast of the socio-economic development of the Russian Federation for the period up to 2020-2030, 337 (2020) 
6. V.I. Suslov, Innovations, 14 (2020)

7. S.V. Popov, D.A. Kolesnichenko, Innovative Development of Russia: Regional Aspect, 36 (2020)

8. K. Yu. Prokofiev, Regional economy: theory and practice, 22 (2017)

9. K. Yu. Prokofiev, Scientific and Technical Bulletin of SPbSPU, Economic Sciences, 94 (2020)

10. J. Schumpeter, Capitalism, Socialism and Democracy, 864 (2010)

11. A.T. Yusupova, Region: Economics and Sociology, 281 (2018) 